\title{
Transformative Adult Learning in New Social Movement - a Case Study from South Africa
}

\begin{abstract}
New social movements in South Africa could play a prominent role in mobilizing the communities to reflect critically and address the repercussions of the neo-liberal agenda which manifests itself in perpetual exclusion of under-educated adults and provision of poor quality education.

Few studies especially from the perspective of the activists leave a potential research area of a very interesting phenomenon of how people learn while struggling for social justice. Therefore this article based on a single multi-site case study on a social movement cohering around literacy issues in Gauteng, South Africa, aims at answering, what forms of learning and education the social movement encompassed, how did the group conscientization occur and what are the individual transformations.

Semi-structured interviews and a focus group discussion were held with 13 learnersactivists and 2 adult educators. By applying Mezirow's individual transformation and Freirean group conscientization models the analysis of primary and secondary data, revealed that the engagement in the social movement challenged and changed learnersactivists' understanding of educational status within their respective communities. This in turn led to transformative action addressing the problems identified. On the individual level, some learners-activists became more tolerant and willing to cooperate with those of different political ideologies, able to tap into community resources. Finally, the potential of social movements as adult learning environments are outlined.
\end{abstract}

Keywords: New social movements, South Africa, transformative learning, conscientization, Freire, Mezirow, individual transformation, experiential learning, popular education, adult education, CLING.

\section{Introduction}

The crucial role of adult education in development is recognized through a number of international declarations ${ }^{1}$, which have been reaffirming the basic right of adults to education since its first mention in the Universal Declaration of Human Rights (UN 1948). Yet the progress of ambitious Education for All goals, two of which are directly related to adult education ${ }^{2}$, is unsatisfactory 
projecting their unlikely achievement by the end of 2015 (UNESCO 2010a, p.18). Moreover, the domination of universal primary education in the global agenda sidelines adult education, which is unfortunate given its possible acceleration to the achievement of all Millennium Development Goals, contribution to the reduction of unemployment and promotion of active citizenship (Ibid, pp.20,43). Adult education receives limited public funding almost in every country of the world. This has resulted in perpetual cycle whereby those having received the least education, continue to receive the least facing various institutional, dispositional and situational barriers refraining them from access to adult education (Ibid, pp.56-57, 67-68).

Critical theory, shedding a light on how "people accept as normal a world characterized by massive inequities and the systemic exploitation of the many by the few", (Brookfield 2005, p.2) is useful in understanding the neglect of adult education. Human resources development theory supporting economic competitiveness in the globalized world views adult education from the economic angle where it should serve the economic growth and productivity. Following the critical theory tradition radical adult educators and researchers (Aitchison, Baatjes, Foley, etc.) criticize the human capital theory driven shift of adult education towards instrumentalism as it is excessively mechanistic, views social inequalities as unavoidable consequences of the only legitimate social institution, the free market (Baptiste 2001, cited in Baatjes\&Mathe 2004, pp.396-397) thus exacerbating the societal inequalities (Foley 2001, p.81). Therefore critical theory offers an alternative, i.e. popular education tradition, aiming to involve people in critical analysis of the social issues where they address inequalities and injustice (Foley 1998, p.140).

Popular adult education, used interchangeably with the radical education tradition in this article, which is rooted in the anti-apartheid struggles of the South African people (Bird 1984, Vally 2007), could play a prominent role in mobilizing the South African communities to critically reflect and address the repercussions of the neo-liberal agenda, manifesting itself in perpetual exclusion of under-educated adults from meaningful democratic citizenship (Baatjes 2002) and the schooling crisis (Vally 2009). Inevitably, radical adult education focusing on social justice and collective action embrace education and learning related to social movements (Foley 1998). The New Social Movements (NSMs) in South African post-apartheid context are defined as "those groups, community based organizations, and individuals that in different forms and expressions challenge the post-colonial and neo-liberal political and social order" (Etzo 2010, p.567).

This article, based on the results of the research conveyed for the master thesis at Lund University, aims to analyze adult learning in the social movement in South Africa cohering around literacy. Adult learning, which occurs both incidentally and through the planned educational intervention in a social 
movement (Newman 2000, pp.267-268) is of particular interest as there is little research on the issue (Foley 1999, pp.134, 140, 143).

The research examines adult learning through a case study based on Community Literacy and Numeracy Groups (CLING), a participatory action research (PAR) project, which is a particular form of popular adult education. It is a method of investigating one's own reality and applying the gained knowledge to change that reality (Brookfield 2005, p.26). Though CLING is a project initiated by external actors, by uniting the community members to strive for improving literacy, it is considered the new social movement.

The study was guided by the principles of critical theory, i.e. particular political analysis criticizing the commodity exchange economic system, was aimed at generating transformative knowledge. It is also normatively grounded (Brookfield 2005, pp.23-29).

\section{Background}

South Africa, which emerged as a democratic country in 1994, is prized as a successful model of the Third Wave of democratization (Madlingozi 2007, p.78). However, the post-apartheid government lead by the African National Congress (ANC) is to be known as "the first government to ever voluntarily seek the help of the World Bank to design and impose a structural adjustment program on its people" (Bond 2000; Marais 2001 cited in Desai\&Pithouse 2004, p.241). Indeed, Growth, Redistribution and Employment (GEAR) policy unveiled in 1996 with the focus on privatization, cuts in government spending, trade liberalization and creation of social justice through economic growth (Madlingozi 2007, p.79; Ballard et al. 2005, p.616) affected strongly the South African communities and gave raise to emergence of the NSMs. The neo-liberal restructuring has intensified unemployment, poverty and inequality, with the GINI index being situated at 58, making South Africa one of the most unequal nations in the world. Poverty rates are also increasing, with population rates of those living on less than $\$ 2$ and $\$ 1.25$ per day having increased by $42.9 \%$ and $26.2 \%$ from 1993 to 2000 respectively (World Bank). Scholars reassert that the racial apartheid was replaced with the class apartheid (Bond 2000, cited in Madlingozi 2007, p.96), however, though the richest income decile of the African origin is growing, "the racial profile of the poor remains black" (Ballard et al. 2005, p. 621).

The instrumentalism of adult education and schooling further marginalizing the poorest communities is closely related to apartheid legacies and neo-liberal political agenda characterizing current South Africa. One of the means of South African apartheid state to sustain the domination of the white minority was centrally controlled separate 
education systems for different racial groups (Hopfer 1997, p.46). Low quality education coupled with unaffordable schooling, schools becoming the site for liberation struggle resulted in the estimated rate of $50 \%$ illiterate adults in 1990 (McKay 2007, pp.287-288; Hopfer 1997, p.47; Baatjes 2002, p.3). Since 1994 a number of literacy campaigns failed (Baatjes 2008, p.218; Baatjes 2010) and though the percentage of adults without complete basic education slightly decreased (from $50 \%$ to 48 \%) between 1996 until 2001, the actual number increased by 1.4 million adults requiring adult education provision (Aitchison\&Harley, 2004 cited in Baatjes 2008, p.209). The research has proved that adult illiteracy mirrors wider disadvantages: the illiterate adults are more likely to be living in poverty, geographically disadvantaged areas, belong to minority groups, are female, either unemployed or working in informal/ agricultural sector (UNESCO 2010b, pp.99-100; Baatjes 2008, p.216).

Adult basic education (ABE), which is only one component of the larger adult education context, is at the centre of adult education in the South African legislation. Despite strong and enabling Adult Basic Education and Training (ABET) legislation (Rule 2006, p.118), it is underfinanced ${ }^{4}$ Baatjes $^{-1}$ 2008), becomes further formalized (Baatjes\&Mathe 2004) and subjugated to maximizing the economic growth thus loosing its emancipatory powers (Aitchison 2004; Baatjes\&Mathe 2004; Rule 2006; Baatjes 2008). Given that unemployment fluctuates between $23 \%$ and $25 \%$ from 2009 to $2011^{5}$ (South African statistics), and legislative framework suggesting skill development leading to employment ${ }^{6}, \mathrm{ABET}$ in its current form and economic situation can do very little to improve the competitiveness of adult learners in the labor market.

The increase of the actual number of under-educated adults indicates the challenges within the formal schooling system (Baatjes 2008, p.211). It is characterized by fee-free schools that are not virtually free, growing disparity between schools in rich and poor communities, poorer students excluded from higher education due to inadequate financial aid scheme, little access to libraries and promotion of the reading culture, inadequate school feeding scheme, unsafe transport, lack of teachers (Vally 2009). GEAR policy means marketization of education, cuts in government spending thus passing most of the education expenditures onto students and their parents and creating further disparities between schools in rich and poor communities, where the latter do not have means to supplement the meager government spending (Vally 2007, pp.48-49).

In summary, instrumentalist ABET, continuous educational inequalities influenced by the macroeconomic government policies further perpetuate marginalization of the poorest South African communities, which is being addressed through the rising NSMs (Baatjes\&Mathe 2004, p.415; Vally 2007, p.49; Ballard et al. 2005, pp.623-624). 
The rise of NSMs in South Africa is well documented and analyzed (Benjamin 2004; Greenberg\&Ndlovu 2004; Ballard et al. 2005; Naidoo\&Veriava 2005; Desai\&Pithouse 2004). To a certain extent all these studies attribute that the rise of NSMs is caused by the neo-liberal government policies further perpetuating poverty and inequality. However, I did not come across to any study on adult learning in South African NSMs except for a few studies from other countries (Foley 1999; Crowther et al. 2007; Walter 2007). Thus this article aims to contribute to a body of research of a very interesting phenomenon on how people learn while struggling for social justice (Opie 1992, cited in Scheyvens\&Leslie 2000, p.127).

\section{Methodology}

The research was a multi-site case study, with the data collected from adult learners-activists from Freedom Park (FP) and Evaton North (EN) (South Africa) CLING groups. The case of CLING is used instrumentally to illustrate the adult learning process (Creswell 1998, p.62) with the embedded analysis of individual and collective learning units (Yin 2003, pp.42-45).

CLING seeks to mobilize the communities in support of literacy and numeracy by applying PAR methodology: the community members work together with the adult educator/ university researcher in analyzing their community needs and designing the activities that support literacy education (CERT 2010, p.10).

Data was collected in February- April of 2011; it involved document analysis, interviews, and observation (Creswell 2007, p.129; Yin 2003, p.83). Thirteen adult activists-learners were purposefully chosen and interviewed. Two semi-structured interviews were conducted with the adult educators involved. Multiple sources allowed data triangulation thus increasing the credibility of the research (Bryman 2004, pp.274-275). The validity of the case study was established through data triangulation and the chain of evidence (Yin 2003, pp.35-36; Bryman 2004, p.275). The issues of external validity are addressed through the clear analytical framework provided in the original study aiding replication and the consultations with the scholar involved in CLING process (Creswell 2007, p.208).

\section{Analytical framework}

The study on which the article is based is an analysis of transformative adult learning in the social movement occurring incidentally and/or facilitated by the radical adult education methodology. The learning is viewed through the lens of experiential adult learning. 
Popular education ${ }^{7}$ embraces education and learning associated with social movements and catalyses them by addressing the issues of social justice (Foley 1998, p.140; Martin 2007, p.5). The educative nature of social movements is intrinsic as they "help to prepare people for change (or for resistance to change) by challenging (or confirming) the ways in which they think and feel and act politically" (Martin 2007, p.10).

Previous research has revealed that people participating in social movements "learn new information, skills, further clarify their values, beliefs, and attitudes; and deepen their sense of self-identity" (Boggs 1986; Foley 1991; Kastner 1993; Scott 1992 cited in Kovan\&Dirkx 2003, p.101), learn to understand and resist social control (Foley\&Flowers 1992 cited in Newman 2000, p.271). However, social movements are not the only learning environments, as adults learn continuously throughout their lives within formal, non-formal, informal education contexts, willingly or unintentionally (Rogers 1992, pp.9-11). Social movements seldom use formal and non-formal education, most of the learning ingrained in action is not recognized as learning (Foley 1999, p.3).

Experience is a valuable part of adult learning: adults bring in their own experience into the learning process; it also forms a part of the learning process as in the case of situated cognition (Merriam\&Caffarella 1999, pp.222, 247). The 'collected' experience can become a basis for future learning as the learners connect their current learning with the previous experience to foresee future implications. To analyze experiential adult learning occurring through the involvement in a social movement, Mezirow's individual transformative learning model and Freire's group conscientization models were applied.

\section{Individual transformative learning}

Mezirow (1990a, p.5) argues that especially in the adult learning process, reflection on the prior learning aiming to verify whether the previous learning is relevant in current circumstances is more important than building new perspectives. Thus transformative learning is mostly connected with the critical reflection validating or changing the previous learning.

Critical reflection is a unifying component in both Mezirow's and Freire's models applied despite the different focus of it (Merriam et al. 2007, pp.140141). Mezirow focuses on individual level, whereas Freire emphasized the collective. Critical reflection as defined by Mezirow (1990a, p.12) aims at "challenging the validity of presuppositions in prior learning" which problematize internalized and taken for granted social roles, expectations, ways of acting and leads to transforming them thus perspective transformation (Mezirow 1981, pp.6-7). The key concept in Mezirow's theory- perspective transformation- is similar to Freire's notion of 'conscientization': both derive from critical reflection and for further validation needs the action connected 
(Freire 1972; Mezirow 1990b). Furthermore, dialogical action is indispensable in the process of unveiling the oppression in Freire's theory (Merriam et al. 2007, p.140) as well as dialogue is inseparable from perspective transformation serving as verification of one's new reality (Mezirow 1990b, p.364; Merriam et al. 2007, p.138).

Individual transformative learning occurs in so called 'frames of reference', which are the assumptions, through which adults understand their experiences. They are culturally influenced, uncritically acquired in childhood through socialization and (un) intentionally learned. For example, through the 'frames of reference' lenses adults distinguish the ugly painting from the beautiful. These 'frames of reference' limits perceptions, cognitions and feelings thus adults often reject the ideas failing to fit their preconceptions and discard them as nonsense (Mezirow 1990a, p.3; Mezirow 1997, pp.5-6). Transformative learning occurs when there is a transformation in 'frames of reference' with the critical reflection facilitating the process (Mezirow 1997, p.6). Mezirow (1991, p.167) says that transformative learning is:

The process of becoming critically aware of how and why our presuppositions have come to constrain the way we perceive, understand and feel about our world; of reformulating these assumptions to permit a more inclusive, discriminating, permeable, and integrative perspective; and of making decisions or otherwise acting upon these new understandings.

Critical reflection may occur while reading a book, hearing a point of view, engaging in task-oriented problem solving, critically reflecting on own ideas (Mezirow 1997, p.7). Challenging situations in the community action, culture of learning and internalization of the lessons learned can also encourage critical reflection (Lovett et al. 1983, p.74).

Perspective transformation occurs when one encounters different 'frames of reference' or experiences a 'disorienting dilemma', e.g. HIV positive status, when old ways of dealing are not sufficient anymore thus causing critical reflection and transformation (Mezirow 1990a, pp.13-14). A person does not make the transformative changes as long as what he/she learns fits comfortably in the existing 'frames of reference' (Mezirow 1997, p.7). Mezirow (1990b, p.363) argues that the individual perspective transformation must occur before the social transformation can succeed, with the individual transformation entailing action, which often means the collective political action.

\section{Freirean group conscientization model}

Freire's theory is based on a divided world between the so-called minorityruling group of the oppressors and the majority consisting of the oppressed. The 
term oppressed entails various disadvantaged groups, e.g. the poor, whereas the oppressors could portray the elite (Mayo 1999, pp.68-69).

Freire argued that the oppressed live in a mythical society promoted by the oppressors, which allow sustaining their powers by advocating the world as fixed, "something to which human beings", as mere spectators, must adapt" (Freire 1972, p.109). Having internalized the myths, the oppressed develop a dual relationship with the oppressors: they want to resist but are also afraid of freedom or the consequences the resistance can bring, e.g. loosing a job (Ibid, pp.22, 114). Freire argued that education in the hands of the oppressors is used as a tool to domesticate the oppressed through so-called 'banking education'. 'Banking education' emphasizes the division between the knowledgeable teacher and ignorant students, where the latter have no control over the learning process or the contents thus the education process stimulate credulity of students therefore serving the interests of the oppressors (Freire 1972, pp.45-59). The knowledge, which is truth only for the oppressors, isolated from the reality, is deposited into the minds of the students as the money is deposited into the bank (Ibid) ignoring that knowledge is a social construct acquired through interaction with other people and is born creating it as subjects (Kane 2001, p.37).

Freire perceived education as politically subjective action (Freire 1985, pp.12, 102), which aims at 'conscientization', i.e. development of the critical consciousness, which would empower the learners to unveil the oppression and mobilize for liberation through transforming the oppressive structures (Freire 1972). The problem-posing education advocated by Freire is based on cognition instead of transmission as in 'banking education', it stimulates critical reflection on reality and the action to change it leading to liberation (Ibid, pp.53-56). 'Conscientization' is a process where the oppressed would start perceiving themselves as subjects of change reflecting critically on the causes of their oppression and considering the possibilities of action for change (Kane 2001, pp.39-40), it also emphasizes the inseparability of action and reflection. Freire (1972, pp.42-43) also emphasized that the liberating practice should involve the political action with the oppressed (original emphasis) instead of carrying it for them (original emphasis).

In summary, firstly the individual must eject the oppressor living inside and unveil the oppressive system he/she lives in through the dialogical action with the others bringing him/her to 'conscientization'. In order to pursue further the act of liberation (as action and reflection are connected), the individual must engage in the struggle with the others (Freire 1972; Gadotti 1994, pp.50-52). Freirean model presents two-level transformation, i.e. community transformation into a powerful actor with members of it simultaneously transforming from bystanders into actors (Rocha 1997, p.38). 


\section{Analysis}

\section{Contextual aspects of learning}

Mezirow's individual transformation theory is criticized for omitting the contextual factors, i.e. individual's biographical history and socio-cultural factors, which shape the nature of the transformative learning (Merriam et al. 2007, p.149). Therefore the political economy of the neo-liberal agenda was shortly presented, the micro-politics of the communities where the research was carried is provided.

The analyzed social movement, i.e. CLING groups, function in FP and EN communities, in Gauteng, South Africa. FP is a semi-formal settlement on the south-west boarder of Soweto, Johannesburg, which was found in 1993. It is a mixture of Reconstruction and Development Programme (RDP) houses and informal housing. EN is situated in Vaal triangle, close to Vereeniging and Vanderbijlpark towns, the area compromises of RDP, bond houses and shacks. The community in Vaal, appeared to be highly organized, with many community initiatives and dynamic young people, and for the project purposes was intentionally paired with FP, which was a newly organizing community showing some level of dynamism (CLING biannual report).

The community mapping and household baseline studies ${ }^{9}$ (table 1) revealed that both communities differ in the levels of education, employment and participation in literacy activities. There are two public primary schools in FP with the nearest high school three to five kilometres away. Primary schools' classrooms are overcrowded; school-feeding scheme is available to certain ethnic groups only. Pupil dropouts were identified as a major issue, only social sciences are promoted. Learners are not active in their mother tongue; it is prohibited to attend classes without a uniform even if the school fees are paid. Forty Vaal triangle primary and secondary schools lack stationery and textbooks, home language classes are overcrowded, and teachers have difficulties in implementing the curriculum (Ibid).

FP is characterized by a high percentage (47\%) of those over 18 who did not complete schooling and are not enrolled in any course, the majority of the respondents have primary level education, whereas in EN most of the respondents have completed high school or post-secondary education. Moreover, though seemingly more educated members of EN community participate in literacy activities more often (30\%) as compared with FP respondents $(18 \%)$, participation in literacy activities on at least weakly basis in EN and FP is rather low, respectively $20 \%$ and $7 \%$ of the respondents ${ }^{10}$.

It was concluded in CLING biannual report that access to literacy materials and programs is almost non-existent. There was no meaningful ABET programme until Kha Ri Gude literacy campaign (launched in 2008 (Kha Ri 
Table 1: Household baseline survey data from EN and FP

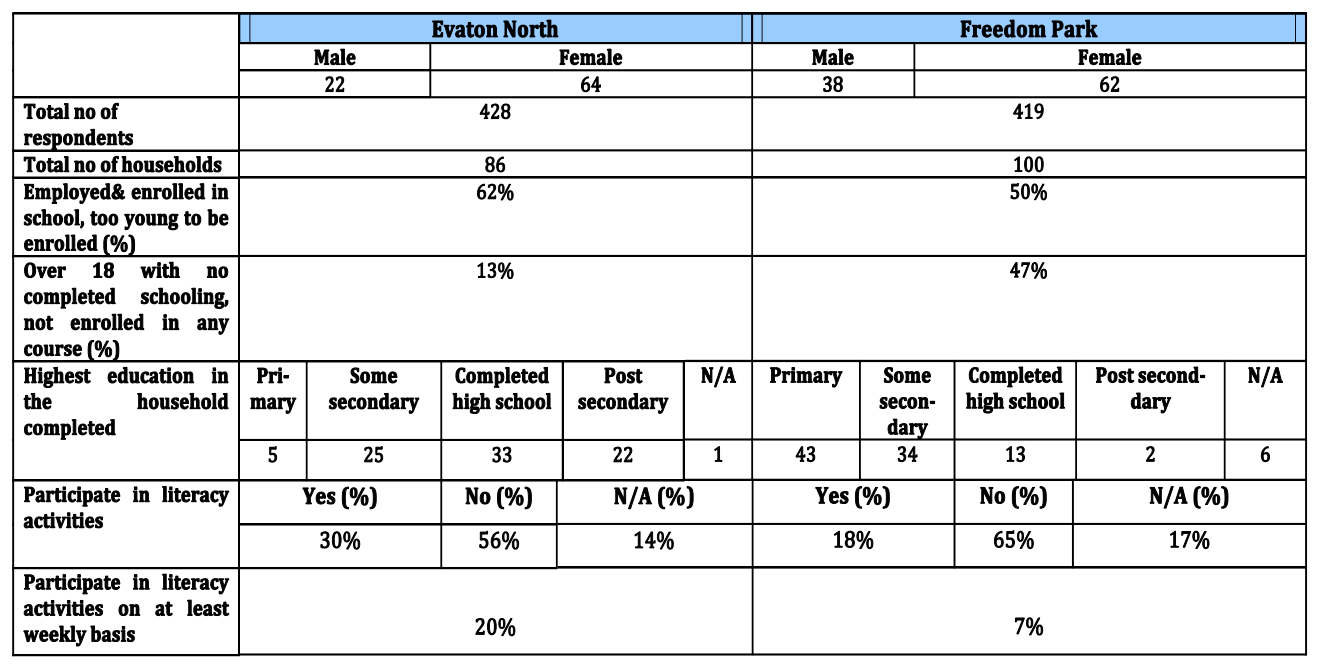

Source: based on the baseline survey data (CLING biannual report)

Gude information)) and until CLING came in there were no libraries within easy reach of the community (CLING report 2008). Limited data still outlines poor schooling conditions, little literacy training opportunities, completion of low levels of formal education, high numbers of school dropouts, high unemployment, that do affect the participation in literacy activities (Lekalala, Francis).

Community mobilization to CLING groups supporting literacy and numeracy activities started in 2007 with the project introductions to different structures in the community and presentations during the community meetings. Community researchers (CRs) were identified based on previous work with Anti-Privatization Forum (APF) and knowledge about the communities. The project staff trained CRs, and they together with Education Policy Consortium (EPC) adult educators played a leading role in mobilizing the community members and organizations to join the CLING groups. At the start of the project, representation of the community at large within CLING group was highly emphasized, though currently there are rather individual community members present in the structure on both sites who feel that they can offer something to the community (CLING biannual report). Each CLING group has a Programme of Action (PoA) with R5000 ${ }^{11}$ per annum provided and stipends for two CRs paid on each site for five years (Gardiner, 2010). CRs act as full members of CLING, they are elected in the governing bodies of the structure, but they also conduct the research on behalf of the project (CLING biannual report). Figure 1 summarizes the specific characteristics of CLING. 
Figure 1: Community Literacy and Numeracy Groups (CLING)

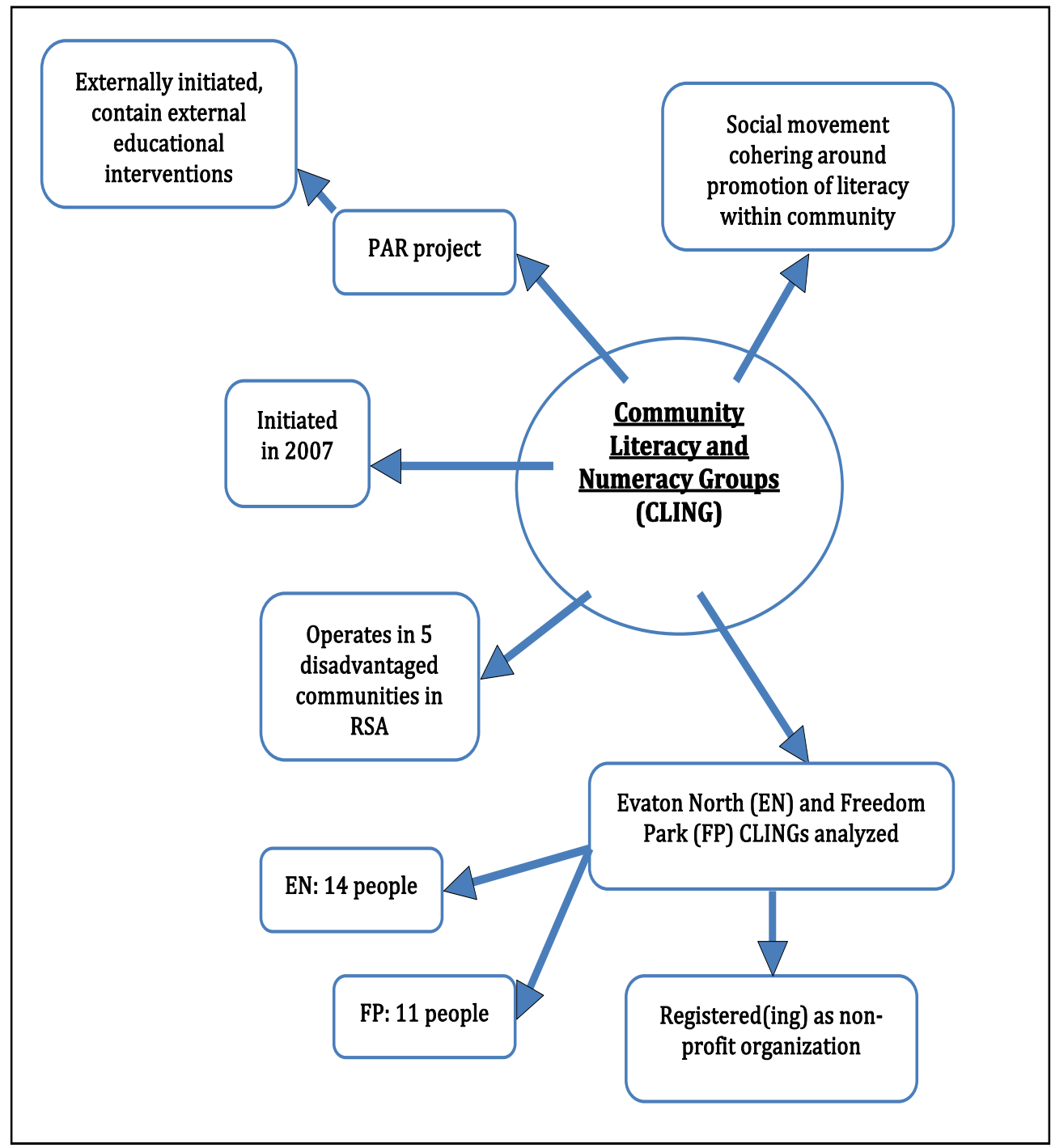

Source: author's creation based on CLING documentation

The following PoA was developed in FP: building the community library, Saturday classes for children, edutainment, i.e. hip-hop sessions and videos, ABET classes (promotional leaflet of CLING in FP), whereas CLING in EN focuses on supporting Early Childhood Development centers and ABET programmes, encouraging elder people to attend ABET classes, temporary library, linking resources within community (Sehlolo, Paki). 


\section{Adult learners-activists}

The distribution by gender of the learners-activists interviewed is presented in table 2.

Table 2: Learners-activists' distribution by gender

\begin{tabular}{|c|c|c|}
\hline & Freedom Park & Evaton North \\
\hline Female & 3 & 4 \\
\hline Male & 3 & 3 \\
\hline Total & $\mathbf{6}$ & $\mathbf{7}$ \\
\hline
\end{tabular}

All learners-activists interviewed differ in terms of their previous involvement in the community. First of all, only two female informants, Adawa and Desla, were not previously involved in the community structures and Tutu was involved only as an educator in Kha Ri Gude literacy campaign. Six other informants, among who four are the CRs, were involved in the community not only through political organizations of APF, GOLCOM or SOPA, but also other structures. Fola, Furaha and Sipho were involved in the local governance structures focusing on basic service delivery, housing and youth, the elderly, children and disability in the community. Shani is an active volunteer and a pastor.

\section{Learning and educational interventions}

To ease the analysis the combination of the experiential learning in CLING was organized into a simplified scheme below.

Firstly, from the data available it is visible that learning and educational interventions ranged from specific training sessions provided by the external actors (Figure 1) to 'learning by doing' followed by the reflection-onaction sessions. CLING, as outlined by Ballard et al. (2005, p.627) is not a spontaneous grassroots appraisal, but a movement relying on the external material and human resources, coming from the involved partners, i.e. Centre for Education Rights and Transformation (CERT) in University of Johannesburg and Centre for Education Policy Development (CEPD). They provided the informal educational interventions, based on popular education principles, and facilitated some reflection-on-action sessions. Reflection-onaction $^{12}$ can be described as reflective monthly meetings of CRs and sometimes other activists from CLING with the adult educators discussing the progress in CLING, problems encountered and planning for the future actions; also national and regional CRs meetings. CLING meetings that are held weekly 
Figure 2: Experiential learning scheme in CLING

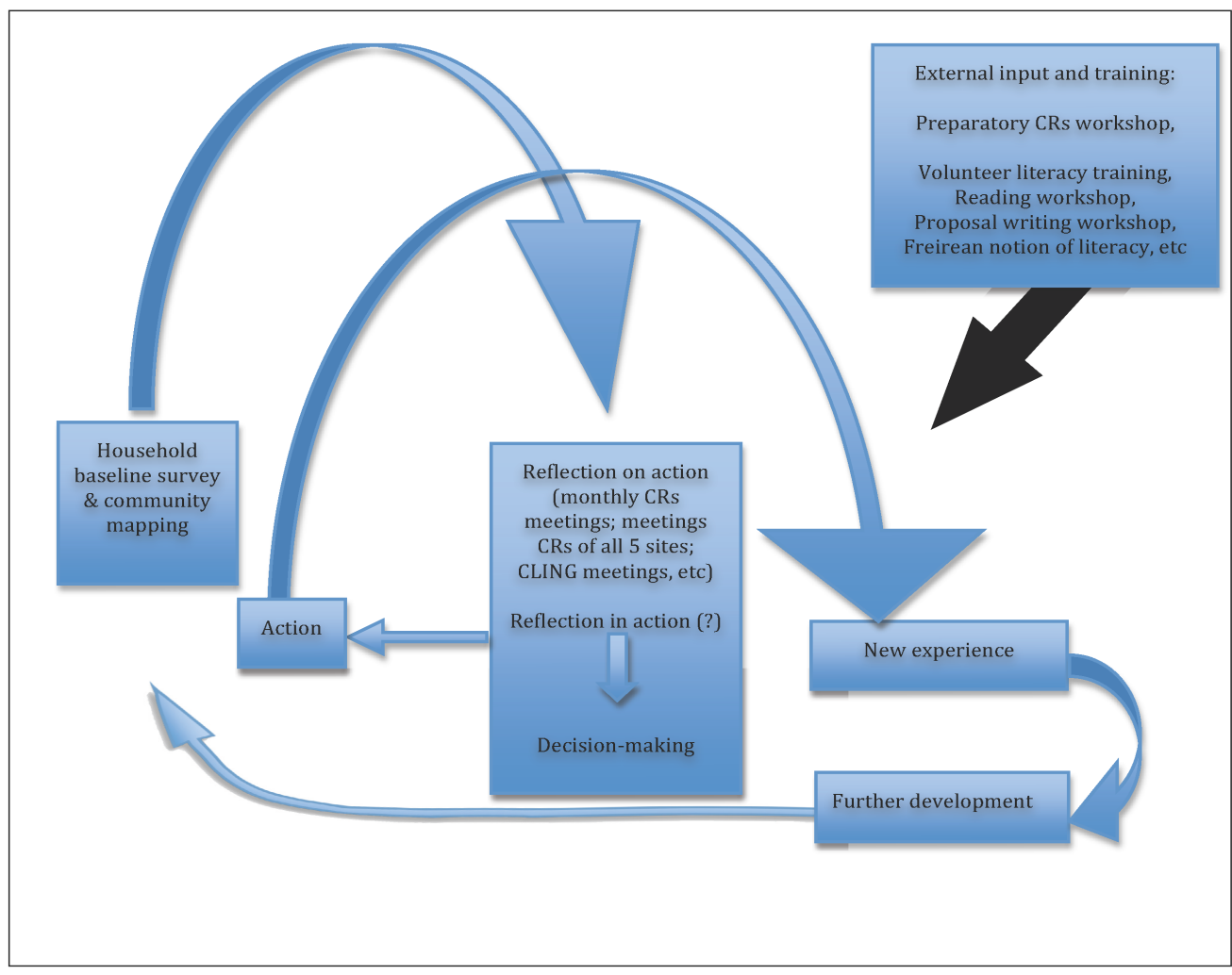

Source: author's creation based on CLING documentation, model adapted from the "Five fold path to development" (Rogers, 1992:144)

in EN and once a month in FP, could be also identified as learning situations with reflection-on-action aspects; still, the involved educators agreed that there wasn't much critical reflection in those meetings (Francis; informal conversation with Baatjes). There is no data confirming or denying the existence of reflection-in-action ${ }^{13}$. From the limited information available, it is visible that the external education and training input was guided by the Freirean notions of critical consciousness, emphasizing the resourcefulness of the communities, outlining the dismal educational situation in the country and organizing for the quality education demands (CLING biannual report; CLING workshop report 2007; CRs workshop minutes 2008; FP CR report 2010).

Though simplifying, it is possible to claim that CLING learning process followed the cyclical pattern. Firstly, learners-activists brought in their multiple experiences from the previous community activisms into the learning process that affected the learning in CLING. Secondly, the understanding of 
the existing state in the community was established through the household baseline survey and community mapping, which was followed by the external input and reflection-on-action sessions. All these elements provided certain experience to be reflected upon, guiding the decision-making of CLING actions and further action that in turn lead to further experiences thus further reflection.

\section{CLING group conscientization}

\section{Conscientization process}

The underlying argument for engagement in the social action is the process of conscientization, which enables the group to understand that the social action is needed and possible (Foley 1999, p.5). Indeed, the fact both CLING groups have been functioning for over five years, allows presuming that the group conscientization process has occurred there. Although caution should be applied in such claims because the group is receiving external support, such as seed money to carry the activities and stipends for CRs (Gardiner 2010), which could serve as motivation to maintain the group structure. Nevertheless, only CRs receive their stipends. Furthermore, EN CLING received their seed money payments only for 2007 (informal conversation with EN CRs), whereas FP CRs did not receive any stipends for the entire 2009 (Francis), but both groups continued existing and implementing CLING's PoAs. Finally, FP already registered CLING as non-profit organization; $\mathrm{EN}$ is in the same process implying the continuation of their work once external project funding is over.

The group conscientization process in both sites is analyzed through the cycle of conscientization, i.e. a learning stance, collective and critical reflection followed by the transformative action, as described by Heany and Horton (1990, pp.89-90). CLINGs learning stance in Gauteng started with the recruitment and initial training of CRs, followed by the community mobilization, i.e. project presentations to the institutions operating in the community, introductory community meetings, CLING formalization meeting, presentation on literacy and numeracy, community mapping facilitated by the CRs and EPC educators ${ }^{14}$ (CLING Gauteng report 2007). The minutes of the initial meetings are not available, thus it is impossible to determine whether the critical reflection started then. Nevertheless the interview data revealed that the externally planned household baseline survey carried out by the activists to some of them played a crucial role in fostering their individual critical reflection about the poor education status in the community:

Through baseline survey - it was when those things that people cannot read and write became clear, especially the adults. $<\ldots>$ They did not have enough education to fulfill their dreams (Fola).

Furthermore, when the household baseline survey information was brought back to the community, the results were questioned (CRs workshop notes 
2008), indicating that the community members were not aware of the poor educational status.

For other members the learning on the poor educational status in their community occurred by implementing CLING programmes themselves (Desla, Samora). Indeed, as Heany and Horton (1990, pp.88-89) emphasize, the educators' role is limited to helping in revelation of the oppression, however, the conscientization can occur only when "learners experience and reflect" (Ibid, p.88). Nevertheless, individual experience, which occurs in the process of the social struggle (Ibid, p.89), forms the basis for critical reflection and leads to conscientization. The quotes of the activists reveal their increasing awareness on dismal education in public schools and the lack of educational resources:

In the community there was no awareness that there is certain knowledge lacking, especially on English. But ever since CLING was there, you could see that there were problems that none of them were aware previously. $\langle\ldots\rangle$ Children can't read, pronounce what is in the book, $<\ldots>$ they cannot write. When I say mother (in English), they would write it as isiZulu (Desla).

Education was the problem that we used to sweep under the carpet. $\langle\ldots>$ With the project we highlighted that we need these resources... We don't have a library... enough schools. $\langle\ldots>$ Now we talk about education... we are realizing that we are having a problem (Samora).

Moreover, work with children conducted after school revealed that the lack of feeding scheme affects their learning (Arusi, Sehlolo, Paki, FP CR report) and poor English influences children's performance at school, especially during the final exams that are conducted in English (Desla).

In the process of consciousness raising and provoking the critical reflection, the importance is attributed to the individual reality instead of "analyses and theories produced elsewhere" (Hart 1990, p.35). Thus though debilitating effects of the apartheid system, high numbers of illiterate adults, growing disparity between schools in rich and poor communities might have been known to the learners-activists, they would not be sufficient to mobilize for the process of conscientization (Hart 1990). Moreover, the context of the community, in which the learners-activists find themselves, facilitates their learning as conscientization occurs among the oppressed/ marginalized groups implying that with no context of oppression, challenging the held assumptions, critical consciousness would not occur.

However paradoxically, critical reflection that leads to critical consciousness, though based on personal experience (Hart 1990, pp.66-67; Foley 1993, p.24), demands theoretical distancing, i.e. "systematic understanding of the nature and complexity of the entire-power bound system" (Hart 1990, p.35). Previous quotes of the activists, reveal theorizing on dismal education status in the community, i.e. failure of public schools, little awareness in the community about the education status and resources needed, based on their personal 
experience gained through engagement in CLING. Nevertheless, it is hard to identify critical reflection occurring only through the engagement in CLING as multiple experiences (among others experiences in personal life, church, political parties) of the activists come into the play (Lovett et al. 1983, p.73), especially taking into consideration active previous involvement of most of the learners-activists.

Their quotes on individual motivation to act in CLING thus attempting to change the educational situation in the community also illustrate the occurrence of critical reflection:

I saw many adults suffering. I want to help older people to read and write especially (Adawa).

This (CLING) programme helps to re-educate the black people and make them look at themselves as perfect human beings (Mfana).

It is clear that the individual understanding of the educational impoverishment of their respective communities has served as a learning stance fostering critical reflection, which has also driven the activists to join CLING in attempt to change the educational situation, thus engage in transformational action leading to critical consciousness. Still it is important to note that transformative learning is not a linear process with the finite outcome of critical consciousness: it develops gradually in the struggle already begun (Heaney\&Horton 1990, p.89). Thus the motivation to act in CLING largely reveals the occurrence of the critical reflection with CLING PoA and its implementation representing the transformative action. Based on the household baseline survey data (FP CLING meeting 2009), PoA addresses both the consequences and factors perpetuating the poor educational status, which aims to change them with the erection of community libraries, afterschool support for the learners, promotion of ABET classes, and the struggle to establish grade 1 and 2 ABET classes, that are not provided by the government in FP. Still the conscientization, fostered by the critical reflection, is an ongoing process.

Conscientization is a dialectical action requiring dialogue to verify one's discoveries (Merriam et al. 2007, pp.138-140). In the case of CLING, reflection-on-action activities might have served that purpose: the notes from the CRs meetings with the adult educators involved and my observation confirms it, though there is no data whether it have occurred during CLING meetings.

Still I noticed the absence of locating the origins of local community problems in the larger framework of neo-liberal policies and how it influences children's poor performance in the public schools available, inexistent and/ or instrumental adult literacy programs, and the shortage of educational resources available thus further increasing marginalization of the communities. A few examples indicating the increased understanding of how the government works, black working class oppression when pursuing the needs of the 
community, framing the community needs in reflection of the undelivered services by the government, and debilitating apartheid influences (Sehlolo, Paki, EN focus group discussion, Moeketsi, Mfana) demonstrate that the systemic oppression has been unveiled. It gives ground to conclude the indepth individual critical reflection and transformation. Having to rely mostly on the individual interviews, the data suggests that critical reflection varies among the learners-activists, though it does not indicate collective critical reflection.

\section{Liberation struggle}

The group conscientization process in Freirean words is the action that involves unveiling the oppression and engaging in transformative action, i.e. liberation struggle, as freedom is not acquired by a gift (Freire 1972, p.24). Indeed, a social action that aims to help people gain more control over the events affecting their lives, i.e. fight the oppression, contains resisting the social control ${ }^{15}$ (Newman 2000, p.271), which is the struggle that in itself is a learning site (Foley 1993). Foley $(1999 ; 1993)$ acknowledged that this struggle could be ambiguous, i.e. it can be liberating or debilitating.

In fact, throughout the transformative action in which CLING's activists engaged aiming to lift the oppression by improving the educational situation in their respective communities, they encountered various obstacles. For instance, CLING members in EN, are involved in the process of acquiring the land for the library. It is a long bureaucratic process, but with little avail as Sehlolo describes:

We struggle to get a land for the shack library, $<\ldots>$ we are renting. $<\ldots>$ But if the government should have said: that's the vacant land... We have identified a number of land that is vacant. $<\ldots>$ But for us to get to a relevant person, that's when the problem comes. $<\ldots>$ We go to the ward councilor, ward councilor says: write letter to a man, who is from department of land $\langle\ldots\rangle$. We write a letter to that person. And then that person says: but no, write a letter to a treasurer.

The obstacles met on the way resulted in learning, as to how the government departments function, reflection upon the racism that black working class South Africans face "as the colour of the skin makes the difference and makes the things move faster" (EN focus group discussion). CLING in EN have not acquired the land yet, but are relying on renting a shack.

Whereas FP activists before starting their learner support program tried to engage with the schoolteachers and learn about the syllabus, which would allow CLING members to support the learners with their schoolwork more effectively. Nevertheless, the attempt resulted in no success with the teachers being afraid that their jobs 'might be taken away'. Currently the activists are relying on the information provided by the children in order to teach in line with the syllabus (Tutu, Samora). 
These examples illustrate the obstacles that the activists encountered while struggling for social justice. In no way it entails that the described obstacles were the only ones as short time in the field allowed just getting a glimpse of the multiple struggles with the government and the educational structures unwilling to (facilitate) change; also diverse conflicts within CLING structures that could also facilitate the learning process (Foley 1993). Though the struggle is subject to various setbacks and obstacles, still it results in personal experience fostering the critical reflection on the oppression leading to transformative action, which results in new experience to be reflected on thus the experiential learning cycle continues. The above given examples show the liberating effects of the struggle as by encountering the obstacles the activists changed their approach, i.e. renting out the library space in EN, relying on the information the children provide in FP. Nevertheless, it must be acknowledged that reflection on lack of material resources and know-how, difficulties in engaging greater numbers of community members in the activities permeating the data deriving especially from FP (Samora; FP CR report 2010; Francis) illustrates debilitating effects of the liberation struggle.

Lack of know-how points to another aspect of the liberation struggle, i.e. inferiority feeling common among the oppressed, which changes once the oppressed engage in the action ejecting the oppressor from within and transforming the oppressive system (Freire 1972, pp.38-41). Interviews revealed increased individual self-confidence of the CLING members emerging through actively changing the educational situation in the community. For example, Fola from EN, who belonged to the representative steering committee in the community previously, claimed that through her involvement in CLING, she gained self-confidence allowing her to engage with the different stakeholders on equal grounds defending the case of the community. The shyness of Moeketsi and Adawa from FP shrank during their involvement in CLING (Lekalala, Adawa); Moeketsi, Mfana, Samora identified their growing confidence to teach adults. Those examples demonstrate increased confidence on the individual level. However, the lack of know-how, focus on the obstacles met (EN focus group discussion; Samora; FP CR report 2010; Francis) point to little collective confidence in both sites.

\section{Instrumental learning}

Both Lovett et al (1983, p.145) and Mezirow (1991, pp.210-211) attributed the importance to the instrumental learning as a preparation for the social action enabling the activists to engage in lifting the oppressive situation. Several education activities took place throughout five years. Most of the learnersactivists participated in the volunteer literacy training (ran in FP in 2009). The learners-activists requested this training recognizing the lack of skills to run the Saturday classes (FP CR report). After the training CLING activists 
reflected that their knowledge on ABET programs increased, subsequently the training provided the learner-activists with the ideas on how to better engage in educational activities with children, and also how to approach the teaching of adults and children differently. Overall this increased learner-activists confidence to teach adults (Fola, Desla, Samora, Moeketsi, Mfana). Furthermore, especially FP activists who are directly involved in the teaching the children observed the difference in running the classes after the training:

It's easier to work now, to understand if kids are listening to us, if they have any problems. $<\ldots>$ Previously we did not have any teaching experience, and also we started to make our teaching in line with the syllabus (Samora).

The reflection on learning from this particular program seems to be richer among the respondents in FP, which could be explained by the fact that they attended all the training workshops that were held in their community, whereas EN respondents participated there sporadically. The need to find funding for transport could have influenced their irregular attendance (Francis).

Other learning in the instrumental domain, acknowledged by the activists, was gained by doing, e.g. knowledge on school syllabus thus increased ability to assist children with their schoolwork (Arusi), ideas of different methodologies to enhance children's reading skills (Tutu). Finally, though only the CRs were trained on data collection and reporting for the university, several respondents in FP emphasized their confidence in organizing door-to-door campaigns, data collection, report writing, conducting the meetings, as those were the activities they were doing in CLING (Moeketsi, Tutu, Samora).

A quick look at the data reveals that richer instrumental learning was identified among the FP activists. It could be explained by the fact, that although respondents in FP, were previously involved in the community activism, there they participated sporadically or did not hold any significant power positions in the community structures, and lacked the know-how (FP CR report 2010). In contrary to that of the EN, thus FP CLING activists gained copious instrumental learning by doing. Foley $(1993,1999)$ noted that most of the learning occurring in the social struggle is incidental, embedded in other activities and might be not articulated as learning by the respondents. Indeed, CLING members established community libraries, run afterschool activities, edutainment sessions, and fundraise, which they were not doing previously. Therefore it provides evidence that the activists learned through the situated cognition setting (initiated by themselves or EPC educators), however, do not fully recognize it yet.

\section{Commentary}

Data analysis reveals movement towards group conscientization both in EN and FP. Firstly, it was ascertained by the occurrence of the individual 
critical reflection, which was fostered by the understanding of the educational deprivation in one's respective community through personal engagement in CLING, external awareness raising and reflection-on-action sessions. Importantly, data also reveal that the understanding of the poor performance of children at schools, lack of feeding scheme affecting the learning, little educational resources within easy reach of the community, debilitating effects of the apartheid education to adults of today, resulted in the necessary theorizing thus framing and understanding the deprivation of the community, i.e. oppression, in a broader setting.

Multiple experiences from previous activism and other social life aspects of the learners coming into the play, as this learning is contextual, make it hard to determine the critical reflection occurring only through the engagement in CLING from the data available. CLING PoA addressing factors and consequences that perpetuate the educational situation, is treated as the reflection of the transformative action indicating the final step in the group conscientization process.

This particular case proves that group conscientization is not a finite outcome that derives from the social action, but rather an ongoing process occurring in the social action. Learning associated with the group conscientization resulted in copious instrumental learning; though the achievements of activists prove rich instrumental learning, much of this learning remain unrecognized by the activists themselves.

Finally, identification of varying levels of individual critical reflection and transformative action indicates the movement towards group conscientization. Mezirow (1990b, p.363) claims that the individual perspective transformation must occur before the social transformation can succeed, thus the limited data allows presuming the ongoing individual transformations leading to critical collective consciousness in Freirean words, which, nevertheless, should be addressed in a later research.

\section{Individual transformation of CLING members}

\section{Accommodating the political differences}

Lovett et al. (1983, p.74) acknowledged that one of the factors fostering critical reflection in the course of action is the activity that "challenges the normal course of things" or in the words of Mezirow (1991, p.168) a 'disorienting dilemma' that challenges the established personal perspectives. Thus one of the observations deriving from the interviews with CRs both in $\mathrm{EN}$ and FP was their acknowledgement of engaging in working relation for the first time with the members from different political groups and especially with the members of the ANC. It's important to note that the political ideas of CRs and especially members of the ANC differ significantly (Benjamin 2006, p.75; Naidoo\&Veriava 2005, p.41, SOPA information). Unfortunately there is no 
data revealing what restrained the activists from working together previously. Throughout the community mobilization process (Lekalala) and seemingly through the entire CLING activists' interaction with EPC educators, the CRs were encouraged to create CLING as a representative community structure and work with those who differ politically (CLING workshop report 2007; FP CLING summary report 2008), which could have served as a challenging action. This experience fostered CLING learners-activists to reflect on their own political beliefs and how they differ:

You find ANC, SANCO there (in CLING) and then the political issues differ. $<\ldots>$ One is to learn to understand how people think, from other parties (Paki).

Mezirow's theory provides tools enabling to explain learning caused by this challenging action and related reflection. It outlines several processes of learning occurring in the 'frames of reference', i.e. elaboration of the existing points of view, establishing new points of view, transforming points of view and transforming habits of mind. With the elaboration of the existing point of view, one seeks for further evidence supporting the held belief; whereas establishment of new points of view means creating new points of view about the new phenomena supporting the existing habit of mind. Transforming points of view and habits of mind is related to critical reflection. Transforming points of view allows changing points of view based on certain experience thus becoming more tolerant to new phenomena. Continuous transformation of points of view can lead to perspective transformation. In the transformation of habit of mind the generalized biases are transformed through critically reflecting on them (Mezirow 1997, p.7).

Thus the quote of the activist from FP exemplifies how engagement with the politically different groups fostered the critical reflection and enabled not to reject contrasting ideas immediately as unworthy as the established 'frame of reference' would guide (Mezirow 1997, p.5), but rather to understand the political differences and ability to learn even from the political opponents:

As an activist you confine to the programme you are doing, you are not much involved with the community at large. You have certain thinking and the more you become involved; you become more open, more involved and debating, transparent. $\langle\ldots>$ Once you actually start to be more involved with the other people, you do not necessarily need to accept other people's ideas, the more you become involved, you start debating and you understand that you learn something from them and they learn something from you. You start to accept different people and accept for what they believe (Moeketsi).

This quote points to transformation occurring, but I would not conclude that it has resulted in the perspective transformation. Because though activists claim to be working with the members from different political groups, the core of FP CLING, which is combined of mostly apolitical and SOPA members, 
proves otherwise thus rather indicating the individual transformation of the point of view.

Whereas in other case, the challenging action lead to the elaboration of the existing points of view as the following quote of the activist in EN illustrate:

They (ANC members) just come down and believe that through negotiations they can achieve. This is how they believe even though it takes longer. What I have learned... that they will forever support their organization, no matter who is doing right or wrong (Paki).

Reflections of the other CRs also reveal that the common working process lead to the elaboration of the existing points of view about politically different groups and especially ANC (Samora, Sehlolo).

\section{Changed approach to community action}

Both EN CRs were actively engaged in the APF, which unites and assists the communities resisting privatization (Naidoo\&Veriava 2005). The activities of APF affiliates differ and combine a range of tactics from institutional to non-institutional/ illegal means of action (marches, pickets, memorandums, negotiations, defiance actions) (Ibid.). The interview with both CRs revealed that within APF they had experience engaging in the non-institutional/ illegal means of action, of what they call the radical approach, to achieving the community development goals and preferring it. Nevertheless, one CR also identified the experience with the institutional means of engagement:

$<\ldots>$ on APF we would automatically challenge the councilors, to be accountable, to deliver the services promised to the community residents $\langle\ldots\rangle$ if there is no library, forcefully APF would demand $<\ldots>$ we would go to the street and barricade in the street, $\langle\ldots\rangle$ toyi- toyi. And we make sure that we get what we want immediately.

I was involved with $\langle\ldots\rangle$ the water privatization case (in $A P F)<\ldots>$ We even went the legal way. $<\ldots>$ If things do not work this way, we open the case for the government- we sue the state (Sehlolo).

During the interview the activists shared, how illegal means of action would make the demands of the community heard and implemented faster than through negotiations and engagement with the local government, which they experienced through their involvement in CLING. Nevertheless, while acting in CLING they had to apply different means of engagement with the government structures, as they must accommodate the political differences present in CLING:

But on CLING I got ANC members that believe that this current government 
will do changes, $<\ldots>$ so I must be in line with them. As much as they believe in approaching them, going to the meetings (Sehlolo).

Work together with the apolitical individuals and members from the different political groups, especially with the supporters of the current ANC government, not revealing their activist background (informal conversation with EN CRs), the need to engage in the negotiations with the local government instead of forceful demands might have served as several 'disorienting dilemmas'. Subsequently they provoked critical self-reflection on the 'frames of reference', which refrained from engaging into the institutional means of action (Mezirow 1991, p.168), as the quote of the activist illustrate:

I was a very radical comrade. $<\ldots>$ but with CLING I was able to engage with them now. Going to their offices. At first I even didn't care that they full me and say: Come, let's sit around the table and discuss that. At first I'd say: to hell with that. But since I am involved with CLING, I say: OK, let me go and hear what they say.

Nevertheless, further analysis confirm that engagement in the institutional actions rather transformed the points of view of EN CRs as they still believe in the effectiveness of the radical approach with the obstacles encountered in the process (exemplified in 6.2.2. section), confirming their existing habits of mind:

With toyi-toying was better.... <..> As much as we do this way, not the wrong way, the right way- still things don't come along.

Emancipatory learning can be graphically illustrated in the simplified cyclical models, however, in reality this type of learning is complex and contradictory (Newman 2000, p.276) with transformation of points of view guiding the action, with multiple experiences feeding the critical reflection and resulting in perspective transformation. Indeed, the following quotes of the CRs illustrates that learning about governmental procedures (occurring through the engagement in the institutional action), obstacles encountered and the identified transformation of points of view, reflection-on-action sessions with the adult educators (CLING biannual report) resulted in new experience on which the critical reflection on the resourcefulness of the community is based:

I think we have found different ways of organizing in the communities that we are involved. And how to start thinking... deep inside in the community; find the resources inside the community. $<\ldots>$ We say, we cannot engage with this capitalist stuff, but at the end of the day they are living in the community and 
there are not plenty of ways of raising funds, but to engage with them. $<\ldots>$ You know how are the small businesses in the communities. We have those ideas of socialist cooperatives how things should move, but $<\ldots>$ it's how you work within the system of the capitalist.

I am checking what the options are to address the existing problem. $<\ldots>$ If there is no library, I won't say, let's go to the street and barricade and demand that the councilor must do it. You see, let's check what is within that community, what can we do. We can collect the books door-to door, so we can start our small library.

These quotes reveal two apparently interwoven trends: a start in perceiving the community as a resourceful agent as well as another transformation of the point of view making it more permeable to cooperation with those who differ politically. Indeed, tapping into the community resources, e.g. in creating the library, co-funding the events (Francis), fundraising with local business even though they are of the capitalist nature opposite to the held beliefs (Paki), actually reveals the occurrence of the perspective transformation. As in the words of Mezirow (1991, p.167), the perspective transformation resulted in reformulating the understanding about the community as a resource and permitting the cooperation with those differing politically if it allows achieving the community action goals raised.

Unfortunately available data from FP learners-activists does not reveal perspective transformation related to the perception of the community as a resource. Nevertheless, their fundraising initiatives for food in local shops for Saturday classes, also among CLING members (Mfana, FP CLING meeting 2010) may indicate the perspective transformation, which should be tested in the future research.

\section{Commentary}

This rather limited analysis evolved around just a few examples of the individual transformation that was the easiest to identify and in no way entail that there are no other individual transformation processes ongoing.

Firstly, as adults bring in their diverse experiences into the learning process, it becomes hard to grasp which experiences contributed and how they actually shaped the transformational process (Lovett et al. 1983, p.73). It was concluded that emphasis on creating CLING as representative community structure, which might have served as an external challenging action fostering critical reflection, resulted in the transformation and elaboration of the existing points of view among CRs with the learners-activists becoming more tolerant to different political ideas, capable to cooperate in achieving the community action goals. Limited data does not allow analysing how previous experiences of the CRs, as community activists and especially within political organizations, which are on the opposite side of the political continuum, influence their current 
experiential learning within CLING. It just points to the existing habits of mind and points of view, which through the engagement in CLING became more inclusive.

The other observation is the transformation of points of view among the EN CRs that resulted in changed means applied to community action. Indeed, as the experience from the institutional approach to community action was subject to obstacles encountered, it lead to further critical reflection and perspective transformation that resulted in perception of the community as a resource which lead to tapping into the community resources.

It is worth noting that individual transformation seems to be identified the easiest among the CRs, who had substantial experience of previous community activism and definitely engaged in critical reflection sessions, i.e. reflection-onaction with EPC educators. This observation in no way entails that individual transformations did not occur among other learners-activists but it should be addressed in future research, developing further the transformation learning theory on how the individual biographic history and socio-cultural factors shape the learning process.

\section{Conclusions}

Until now there has been limited data available to make firm conclusions about complex transformative learning processes occurring, with the theory offering limited guidance in addressing multiplicity of issues affecting this type of learning (Taylor 1997).

Nevertheless, on the basis of data reviewed here, it can be concluded that learners-activists engagement in the social movement cohering around literacy issues resulted in the ongoing individual transformations and movement towards group conscientization, and copious instrumental learning which subsequently supported the engagement of the activists.

Firstly, learning of the activists evolved around informal educational interventions and incidental learning. The informal educational interventions facilitated the occurrence of the critical reflection on the dismal education status in learners-activists' respective communities, challenging perceptions held about different political groups and their respective communities. Combination of incidental learning, with multiple experiences deriving from the engagement in action, previous activism and educational interventions fostered the critical reflection and lead to ongoing individual and collective transformations. Furthermore, learners-activists gained skills and knowledge from the external educational interventions and through 'learning by doing', however, the learners-activists do not recognize this learning yet.

The identification of the critical reflection and the related transformative action allows concluding the movement towards group conscientization 
and individual transformations. Learners-activists experience in the social movement challenged and changed their understanding of their respective communities. They deepened their awareness on how poor children's performance is influenced by the quality of education provided in the public schools, how restricted access to educational resources limits participation in literacy activities, how adult illiteracy affects personal life and participation in the social life. Instead of waiting for saviors to come, they engaged in (re)creating the alternative institutions within their respective communities addressing the problems identified. Nevertheless, by bringing forward the community needs, they also experienced that uplifting the systemic oppression is a fight that does not necessarily lead to liberation but also to debilitation which either encourages finding the alternative solutions or demoralizes.

On the individual level at least the CRs became more tolerant and willing to cooperate with those differing politically by placing the community interests first. In addition, their thinking from believing in external support moved to seeking for resources within the community themselves.

Finally, there are no magic wand-waving solutions involved in this particular social movement (Gardiner 2010) while addressing the marginalization of the communities perpetuated by the neo-liberal government agenda: the process is subject to conflicts and obstacles. Sehlolo accurately describes it: "we go one step forward, two steps back". Nevertheless the research shows the communities and learners-activists' resilience in finding alternative local solutions and indicates the empowering learning environment for adultlearners activists. Indeed, it is a learning environment where " $<\ldots>$ no one teaches another nor anyone is self-taught. People teach each other mediated by the world" (Freire 1972, p.53). This learning environment significantly changes the understanding of the learners-activists involved and fosters the ability to pursue social, economical and political freedoms leading to development as freedom as Sen (1999) perceived it.

To conclude, popular education offers one more route to development. It emphasizes the empowerment of the communities and individuals through learning from own experience, by critically reflecting on how social relations and politics shape one's reality, and showing that one is capable to become an active agent in transforming it.

\section{References}

Aitchison, J., 2003a. Struggle and compromise: a history of South African adult education from 1960 to 2001. Journal of Education, 29, pp.123-178.

Aitchison, J., 2003b. Brak!- vision, mirage and reality in the post apartheid globalisation of South African adult education and training. Journal of Education, 31. pp.47-74.

Aitchison, J., 2004. Lifelong learning in South Africa: dreams and delusions. 
International Journal of Lifelong Education, 23(6), November- December, pp.517-544.

Baatjes, I., 2002. The new knowledge-rich society: perpetuating marginalisation and exclusion. Proceedings of the International Conference on technical and Vocational Education and Training. Developing skills fore the new economy, 17 to 19 October 2002, Winnepeg, Manitoba, Canada, 17-19 October 2002. Available at: $<$ http://www.umanitoba.ca/unevoc/2002conference/text/proceedings. shtml $>$ [Accessed 26 February 2011].

Baatjes, I., 2008. Adult basic education and training. In: Kraak, A. and Press, K., eds., Human resources development review 2008. Education, employment and skills in South Africa. Cape Town: HSRC press.

Baatjes, I., 2010. Where is the public outcry?, in Mail and Guardian, 2010, November 12. Available at: $<$ http://www.mg.co.za/article/2010-11-12-where-is-the-publicoutcry $>$ [Accessed 24 February 24].

Baatjes, I. and Mathe, K., 2004. Adult basic education and social change in South Africa, 1994 to 2003. In: Chisholm, L. ed., Changing class: Education and social change in post-apartheid South Africa, HSRC press. Available at: $<\mathrm{http}: / /$ www.hsrcpress.ac.za/product.php?productid $=1937 \&$ freedownload $=1>$ [Accessed on 10 January 2011].

Ballard, R., Habib, A., Valodia, I. and Zuern, E., 2005. Globalization, marginalization and contemporary social movements in South Africa. African Affairs, 104(417), pp.615- 634 .

Benjamin, N., 2004. Organisation building and mass mobilisation. In: McKinley\&Naidoo, guest eds., Development update. Mobilizing for change. The rise of the new Social Movements in South Africa, 5 (2), November 24, Johannesburg: Interfund, pp.79- 93.

Bird, A., 1984. The adult night school movements for blacks on Witwatersrand 1920- 1980. In: Kallaway, P., ed., Apartheid and education. The education of black South Africans. Johannesburg: Ravan press.

Brookfield, S., D., 2005. The power of critical theory. Liberating adult learning and teaching. San Francisco: Jossey- Bass.

Bryman, A., 2004. Social Research Methods. Oxford: Oxford University Press.

CERT, 2010. Annual report 2010. University of Johannesburg.

Creswell, J.W., 1998. Qualitative Inquiry and Research Design: Choosing Among Five Approaches. Thousand Oaks: Sage.

Creswell, J.W., 2007. Qualitative Inquiry and Research Design: Choosing Among Five Approaches. Thousand Oaks: Sage.

Crowther, J., Martin, I. and Shaw, M., eds., 2007. Popular education and social movements in Scotland today. NIACE, UK.

Desai, A. and Pithouse, R., 2004. 'But we were thousands': dispossession, resistance, repossession and repression in Mandela park. Journal of Asian and African studies, 39, pp.239-269. 
Etzo, S., 2010. 'The unfinished business of democratization': struggles for services and accountability in South African cities. Democratization, 17(3), pp.564-584.

Foley, G., 1993. The neighbourhood house: site of struggle, site of learning. British Journal of Sociology of Education, 14 (1), pp.21-37.

Foley, G., 1998. Clearing the theoretical ground: elements in a theory of popular education. International Review of Education, 44 (2/3), pp.139-153.

Foley, G., 1999. Learning in social action: a contribution to understanding informal education. Zed Books, London in association with IIZ-DVV, Bonn.

Foley, G., 2001. Radical adult education and learning. International Journal of Lifelong Education, 20 (1/2), January- April, pp.71-88.

Freire, P., 1972. Pedagogy of the oppressed. London: Penguin books.

Freire, P., 1985. The politics of education: culture, power and liberation. New York: Macmillan.

Freire, P., 2004. Pedagogy of hope. Reliving pedagogy of the oppressed. Continuum, New York.

Gadotti, M., 1994. Reading Paulo Freire. New York: State University of New York Press.

Greenberg, S. and Ndlovu, N., 2004. Civil society relationships. In: McKinley\&Naidoo guest eds., Development update. Mobilizing for change. The rise of the new Social Movements in South Africa, 5 (2), November 24, Johannesburg: Interfund.

Hart, M.U., 1990. Liberation though consciousness raising. In: Mezirow, J. and associates: Fostering critical reflection in adulthood. A guide to transformative and emancipatory learning. San Francisco: Jossey- Bass publishers.

Heaney, T.W. and Horton, A.I., 1990. Reflective engagement for social change. In: Mezirow, J. and associates, Fostering critical reflection in adulthood. A guide to transformative and emancipatory learning. San Francisco: Jossey- Bass publishers.

Hopfer, C., 1997. Empowering adult education in Namibia and South Africa during and after apartheid. International Review of Education, 43(1), pp.43-59.

Kane, L., 2001. Popular education and social change in Latin America. LAB, UK.

Kha Ri Gude information. Available at: <www.kharigude.co.za $>$ [Accessed 15 May 2011].

Kovan, J.T. and Dirkx, J.M., 2003. ''Being Called Awake”: The Role Of Transformative Learning In The Lives Of Environmental Activists. Adult Education Quarterly, 53(2) February, pp.99-118.

Lovett, T., Clarke, C. and Kilmurray, A., 1983. Adult education and community action. Radical forum on adult education series. London: Croom Helm.

Madlingozi, T., 2007. Post- apartheid social movements and the quest for the elusive 'new' South Africa. Journal of Law and Society, 34(1), pp.77-98.

Martin, I., 2007. Introductory essay: popular education and social movements in 
Scotland today. In: Crowther, J., Martin, I. and Shaw, M. eds., Popular education and social movements in Scotland today. London: NIACE.

Mayo, P., 1999. Gramsci, Freire and adult education. Possibilities for transformative action. New York: Zed books.

McKay, V., 2007. Adult basic education and training in South Africa. Review of Adult Learning and Literacy. A Project of the National Center for the Study of Adult Learning and Literacy, NCSALL, South Africa, Volume 7, pp.285310. Available at: <http://www.ncsall.net/index.php?id=493> [Accessed 26 February 2011].

Merriam, S.B. and Caffarella, R.S., 1999. Learning in adulthood. A comprehensive guide. $2^{\text {nd }}$ edition. San Francisco: Jossey- Bass publishers.

Merriam, S.B., Caffarella, R.S. and Baumgartner, L.M., 2007. Learning in adulthood. A comprehensive guide. $3^{\text {rd }}$ edition. New York: John Wiley\& Sons, Inc.

Mezirow, J., 1981. A critical theory of adult learning and education. Adult Education, 32(1), Fall, pp.3-24.

Mezirow, J., 1990a. How critical reflection triggers transformative learning,. In: Mezirow, J. and associates, Fostering critical reflection in adulthood. A guide to transformative and emancipatory learning. San Francisco: Jossey - Bass publishers.

Mezirow, J., 1990b. Conclusion: toward transformative learning and emancipatory education. In: Mezirow, J. and associates, Fostering critical reflection in adulthood. A guide to transformative and emancipatory learning. San Francisco: Jossey- Bass publishers.

Mezirow, J., 1991. Transformative dimensions of adult learning. San Francisco: Jossey- Bass publishers.

Mezirow, J., 1997. Transformative learning: theory to practise. New Directions for Adult and Continuing Education, 74, summer, pp.5-12.

Naidoo, P. and Veriava, A., 2005. Re-membering movements: trade unions and new social movements in neoliberal South Africa. In: From local processes to global forces. Centre for civil society. Research reports: 2005, Vol. 1.

Newman, M., 2000. Learning, education and social action. In: Foley, G., ed., Understanding adult education and training. $2^{\text {nd }}$ edition. Crows Nest: Allen \& Unwin.

Rocha, E.M., 1997. A Ladder of Empowerment. Journal of Planning Education and Research, 17 (31).

Rogers, A., 1992. Adults learning for development. London: Cassell.

Rule, P., 2006. "The time is burning": The right of adults to basic adult education in South Africa. Journal of Education, 39, pp.113-135.

Sen, A., 1999. Development as freedom. Oxford: Oxford University press.

Scheyvens, R. and Leslie, H., 2000. Gender, ethics and empowerment: dilemmas of development fieldwork. Women's Studies International Forum, 23(1), pp.119-130. 
Socialist Party of Azania (SOPA) information. Available at: <http://en.wikipedia.org/ wiki/Socialist_Party_of_Azania> [Accessed 1 May 2011].

South African statistical data. Available at: <www.statssa.gov.sa $>$ [Accessed 16 May 2011].

Taylor, E.W., 1997. Building upon the theoretical debate: a critical review of the empirical studies of Mezirow's transformative learning theory. Adult Education Quarterly, 48 (1), Fall, pp.34-59.

The World Bank statistical data, on South Africa. Available at: <http;//data.worldbank. org/country/south-africa $>$ [Accessed 20 March 2011].

Torres, C.A., 2005. Participatory action research and popular education in Latin America. In: McLarren, P. and Giarelli, J.M., eds., Critical theory and educational research. New York: State University of New York Press.

United Nations, 1948. The Universal Declaration of Human Rights. Available at: $<$ http;// www.un.org/en/documents/udhr/index.shtml $>$ [Accessed 7 March 2011].

UNESCO, 2000. The Dakar Framework for Action. Education for All: Meeting our Collective Commitments. Adopted by the World Education Forum. Dakar, Senegal, 26-28. April 2000, Paris: UNESCO. Available at: <http://unesdoc. unesco.org/images/0012/001211/121147e.pdf> [Accessed 6 March 2011].

UNESCO, 2010a. Global report on adult learning and education. Available at: $<$ unesdoc. unesco.org/images/0018/001864/186431e.pdf> [Accessed 6 March 2011].

UNESCO, 2010b. Progress towards the EFA goals, chapter 2 in Reaching the marginalized. Education for All global monitoring report 2010, Paris. Available at: <www.unesco.org/education/gmr2010/ch2.pdf> [Accessed 7 March 2011].

Vally, S., 2007. From people's education to neo-liberalism in South Africa. Review of African Political Economy, 34(111), pp.39-56.

Vally, S., 2009. Education: from crisis to national disaster. Amandla!, 8, June/ July, 2009.

Walter, P., 2007. Struggle for the Clayoquot Sound Rainforest Adult Learning in New Social Movements: Environmental Protest and the Struggle for the Clayoquot Sound Rainforest. Adult Education Quarterly, 2007, 57 (3) May, pp.248-263.

XE currency conversion information. Available at: $<$ www.xe.com $>$ [Accessed 7 June 2011].

Yin, R.K., 2003. Case Study Research: Design and Methods, Thousand Oaks: Sage.

\section{CLING documentation:}

CLING biannual report: two- year review of the CLING project. Gauteng, July 2007 to June 2009 
CLING Gauteng report, 2007 November, prepared for the $3^{\text {rd }}$ national CLING workshop on 2007 November 15

CLING Gauteng report, 2008 October

CLING workshop report, 2007 September 27

CR's workshop notes, 2008 June 24- 25

FP CLING meeting notes, 2009 November 22

FP CLING meeting minutes, 2010 May 4

FP CLING summary report of progress since inception, 2008 February 22

FP CR report: CLING report and reflection of events of research. 2010, NovemberDecember

FP CR report: community research report and events. No date

Gardiner, M., 2010: CLING project activities. Available at: <www.cepd.org.za/files/ CLING_activities_May2010.pdf $>$ [Accessed 11 March 2011].

Promotional leaflet of CLING project in Freedom Park

\section{Semi- structured interviews:}

Moeketsi (Freedom Park), notes taken during interview, March 2, 2011

Samora and Tutu (Freedom Park), notes taken during interview, March 2, 2011

Adawa (Freedom Park), notes taken during interview, March 5, 2011

Arusi (Freedom Park), recorded interview, March 8, 2011

Tutu (Freedom Park), recorded interview, March 22, 2011

Samora (Freedom Park), recorded interview, March 22, 2011

Sehlolo and Paki (Evaton North), recorded interview, March 31, 2011

Makoma Lekalala (EPC researcher until 2008), recorded interview, April 5, 2011

Vanessa Francis (EPC researcher), recorded interview, April 6, 2011

Fola (Evaton North), recorded interview, April 7, 2011

Desla (CLING member, Evaton North), recorded interview, April 7, 2011

Samora (Community researcher, Freedom Park), recorded interview, April 10, 2011

Moeketsi (Community researcher, Freedom Park), recorded interview, April 11, 2011

\section{Focus group discussion}

Furaha, Shani and Sipho (CLING members, Evaton North), recorded discussion, April 13, 2011 
List of acronyms

$\begin{array}{lll}\text { ABE } & - & \text { Adult Basic Education } \\ \text { ABET } & - & \text { Adult Basic Education and Training } \\ \text { APF } & - & \text { Anti- Privatization Forum } \\ \text { CEPD } & - & \text { Centre for Education Policy Development } \\ \text { CERT } & - & \text { Centre for Education Rights and Transformation } \\ \text { CLING } & - & \text { Community Literacy and Numeracy Groups } \\ \text { CRs } & - & \text { Community Researchers } \\ \text { EN } & - & \text { Evaton North } \\ \text { EPC } & - & \text { Education Policy Consortium } \\ \text { FP } & - & \text { Freedom Park } \\ \text { GEAR } & - & \text { Growth, Employment and Redistribution Policy } \\ \text { GOLCOM } & - & \text { Golden Triangle Community Crisis Committee } \\ \text { HIV } & - & \text { Human Immunodeficiency Virus } \\ \text { NGO } & - & \text { Non-governmental Organization } \\ \text { NSM } & - & \text { New Social Movement } \\ \text { OECD } & - & \text { Organisation for Economic Co-operation and Development } \\ \text { PAR } & - & \text { Participatory Action Research } \\ \text { PoA } & - & \text { Programme of Action } \\ \text { RDP } & - & \text { Reconstruction and Development Programme } \\ \text { SOPA } & - & \text { Socialist Party of Azania } \\ \text { UNESCO } & - & \text { United Nations Educational, Scientific and Cultural Organisation }\end{array}$

\section{Notes}

1 UNESCO First International conference on adult education, 1949; Montreal, 1960; Tokyo, 1972; Recommendation on the development of adult education, Nairobi, 1976; Paris, 1985; Hamburg declaration on adult learning, 1997; Dakar framework of action, 2000.

2 3. Ensuring that the learning needs of all young people and adults are met through equitable access to appropriate learning and life-skills programs; 4 . Achieving a $50 \%$ improvement in levels of adult literacy by 2015, especially for women, and equitable access to basic and continuing education for all adults; (UNESCO, 2000).

3 The richest income decile of the African origin grew from $9 \%$ in 1991 to $22 \%$ in 1996 (Ballard et al, 2005:621).

4 Though the spending on ABET since 1995/6 has increased by about 33\% each year, by 2003 only $2 \%$ of the total Department of Education (DoE) budget was allocated to ABET; external donor funding has declined (Baatjes, 2008:219).

5 Some sources refer to 40\% unemployment in 2003 (McKay, 2007:289). 
6 South African Qualifications Act (1995); Skills development act (1998); Skills development levy act (1999); Adult basic education and training act (2000); Further education and training act (2006)

7 Popular education is an educational practice, which is rooted in the real interests and struggles for ordinary people; is overtly political and critical of the status quo; is committed to progressive social and political change (Martin, 2007:4).

8 Originally in the Pedagogy of the Oppressed (Freire, 1972), the term 'men' was used to describe people, human beings, etc. However, Freire was criticized widely for not being explicit that men also involve women thus writing in a sexist language, therefore as suggested by Freire himself, the sexist nature of his language in citations was changed by the author of this paper (Taylor, 1993 cited in Kane, 2001:49; Freire, 2004).

9 Conducted by the Community Researchers (CRs) in each site.

10 Some of the data captured during the household baseline survey could be questioned for reliability as it seems not making sense (CLING biannual report), thus the statistical data revealing that from 419 respondents in FP, only 18 are employed whereas from 428 in EN 89 are employed, is not cited and discussed further in the main body of text, though it could outline the poor socio-economic conditions in FP community.

11 It is approximately 505 Euros (XE currency conversion information).

12 Reflection-on-action is consciously returning to experienced situations to think through and reevaluate them (Merriam\&Caffarella, 1999:235).

13 Reflection-in-action is thinking on situation once you are in it (Merriam\&Caffarella, 1999:236).

14 Makoma Lekalala and Vanessa Francis by that time.

15 Social control entail brute force, voluntary submission in exchange of the institutional membership or hegemonic control, which is Freirean words is the mythical society, when 'commonsense' mythical truths favoring one group over the other are channeled and become internalized by the oppressed (Newman, 2000:271-272; Freire, 1972:109-114).

\section{About Author}

\section{Marta ČUBAJEVAITÉ}

She holds a Master's Degree in International Development and Management from Lund University. Since 2015 she is a PhD student at Vytautas Magnus University researching Lithuanian development cooperation policies. Her research interests are sustainable development, Lithuanian and the EU development cooperation policies, social movements and non-governmental organizations. Besides pursuing an academic career, she is currently heading the Lithuanian Non-Governmental Development Cooperation Organisations' Platform and has been working with numerous international development and development (global) education projects.

m.cubajevaite@gmail.com 